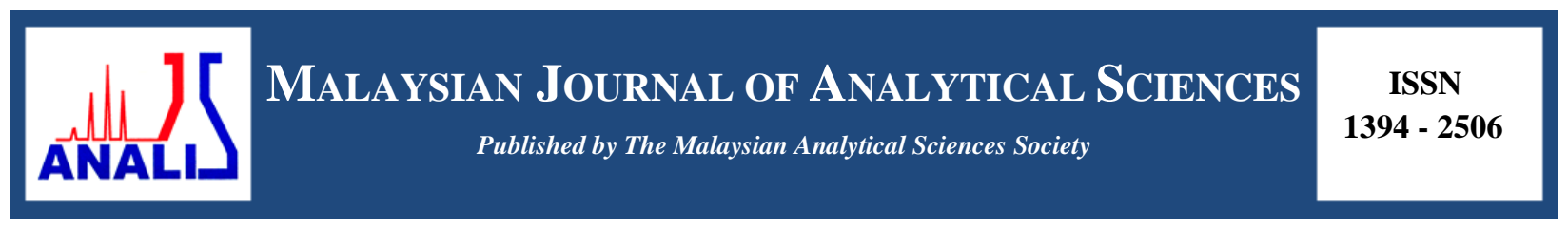

\title{
PREPARATION OF MEMBRANE ELECTRODE ASSEMBLY FOR HIGH PERFORMANCE OF FORMIC ACID FUEL CELL
}

\section{(Penyediaan Himpunan Membran Elektrod untuk Sel Bahanapi Asid Formik Berprestasi Tinggi)}

\author{
Norraihanah Mohamed Aslam ${ }^{1}$, Mohd Shahbudin Masdar ${ }^{1,2 *}$, Siti Kartom Kamarudin ${ }^{1,2}$ \\ ${ }^{I}$ Fuel Cell Institute \\ ${ }^{2}$ Department of Chemical and Process Engineering, Faculty of Engineering and Built Environment \\ Universiti Kebangsaan Malaysia, 43600 UKM Bangi, Selangor, Malaysia \\ *Corresponding author: shahbud@ukm.edu.my
}

Received: 5 February 2016; Accepted: 22 April 2016

\begin{abstract}
This study is focused on development of membrane electrode assembly (MEA) for direct formic acid fuel cell (DFAFC). The effects of the backing layer, the loading of the gas diffusion layer (GDL), the carbon structures and the electrolyte membrane types, and fuel concentrations on the DFAFC's performance are investigated. Two types of backing layer are used in either a carbon paper (CP) or carbon cloth (CC) form, and three different types of carbon structures, carbon black (CB), carbon nanofiber $(\mathrm{CNF})$ and carbon nanotube (CNT), are studied. A single cell DFAFC is tested to obtain the performance of the MEA, including the open circuit potential (OCP), current density, and power density. From the results, carbon paper indicates a much better performance than carbon cloth and gas diffusion layer (GDL) with $1 \mathrm{mg} \mathrm{cm}^{-2}$ loading shows a uniform surface morphology under scanning electron microscopy (SEM) and records a higher power density than $2.5 \mathrm{mg} \mathrm{cm}^{-2}$. Moreover, it is found that the power density increases with increase of the formic acid concentration up to an optimum concentration. However, the optimum fuel concentrations are different for each type of carbon structure. The highest power density is obtained using a combination of $\mathrm{CNT}$ and electrolyte membrane of Nafion 117 at $18.36 \mathrm{~mW} \mathrm{~cm}^{-2}$ using $10 \mathrm{M}$ fuel concentration.
\end{abstract}

Keywords: electrode; performance, microporous, characteristic, direct formic acid fuel cell

\begin{abstract}
Abstrak
Kajian in tertumpu kepada pembangunan himpunan membran elektrod (MEA) untuk asid formik sel bahanapi langsung (DFAFC). Kesan lapisan sokongan, kandungan lapisan resapan gas (GDL), struktur karbon and jenis membran elektrolit, serta kepekatan bahan api terhadap prestasi DFAFC diselidiki. Dua jenis lapisan sokongan sama ada kertas karbon mahupun kain karbon, dan tiga jenis struktur karbon; karbon hitam (CB), nano-serat karbon (CNF) dan nano-tiub karbon (CNT) digunakan dalam kajian ini. Sel tunggal DFAFC diuji untuk memperoleh prestasi MEA termasuk keupayaan litar terbuka (OCP), ketumpatan arus dan ketumpatan kuasa. Berdasarkan hasil kajian, kertas karbon menunjukkan prestasi yang lebih baik berbanding kain karbon. Manakala, GDL dengan kandungan $1 \mathrm{mg} \mathrm{cm}^{-2}$ menunjukkan morfologi permukaan yang seragam di bawah mikroskop pengimbas elektron (SEM) dan merekodkan ketumpatan kuasa yang lebih tinggi berbanding $2.5 \mathrm{mg}^{-2}$. Sementara itu, ketumpatan kuasa meningkat dengan peningkatan kepekatan asid formik sehingga kepekatan optimum. Ketumpatan kuasa yang tertinggi diperoleh melalui kombinasi CNT dan membran elektrolit Nafion 117 pada nilai 18.36 mW $\mathrm{cm}^{-2}$ menggunakan kepekatan bahan api $10 \mathrm{M}$.
\end{abstract}

Kata kunci: elektrod, prestasi, mikroporos, pencirian, asid formik sel bahanapi langsung 


\section{Introduction}

A fuel cell is a source of renewable energy which excludes the combustion process. Hence it does not release any harmful pollution as a side-product of the reaction. Direct formic acid fuel cell (DFAFC) is one of the fuel cell type which has a higher open circuit potential (OCP), at $1.40 \mathrm{~V}$, than the proton exchange membrane fuel cell (PEMFC) $(1.23 \mathrm{~V})$ and direct methanol fuel cell (DMFC) $(1.18 \mathrm{~V})$. Therefore, the DFAFC has a high potential to be commercialized as a microfuel cell due to its high output power compared to other liquid fuel cells like DMFC [1] and it is the most suitable technology to replace the battery.

The membrane electrode assembly (MEA) is the heart of a fuel cell, where the main electrochemical reaction takes place and produces electricity. Hence, it is the most crucial part of the fuel cell as well as the direct formic acid fuel cell (DFAFC) [2]. Currently, there are a lot of studies focusing on the optimizing the MEA for the fuel cell [3-5]. However, the conventional characteristics of an anode may not be suitable for the DFAFC due to its formic acid properties. As a result, formic acid fuel presents the difficulty of mass transport constraints through absorption media in the anode, which is usually in a hydrophobic condition [6]. For instance, the Nafion content in the GDL will increase the proton transport moving towards the cathode [7]. The mass transport constraints on the anode depend on the nature of the anode absorption media and formic acid concentrations. This constraint is due to the hygroscopic nature of formic acid in the absorption of hydrophobic media [8]. Therefore, it is necessary to develop a good anode as well as anode absorption media and MEA, including the formulation and the types of materials to overcome the mass transport constraints at the DFAFC's anode.

Based on Sharma and Pollet [9], CB is a conventional catalyst support used for the platinum (Pt) catalyst and Pt alloys in the research and commercialization of fuel cells. However, the use of CB is constrained by problems such as the presence of sulfur impurities and pores that trap microporous nanoparticle catalyst. This means that the active site of reaction cannot be reached by the reactants, resulting in deterioration of the catalytic activity. Zainoodin et al. conducted a study on the effects of the porous layer structure at the anode on the performance of DMFCs. They used three types of carbon powder structures; CB, mixtures of CB and CNF, and CNF. From the results, it was found that the CNF structure recorded a higher performance for methanol concentration in the range of 2 to $5 \mathrm{M}$ [10]. This explains the impact of high electrical conductivity and good use of the catalyst in CNF as the GDL for DMFCs.

Generally, the fuel of formic acid has better compatibility with Nafion membrane [1] than methanol in DMFCs. However, formic acid also has a certain limit of concentration to prevent a high fuel crossover from the anode to the cathode, and this reduces the DFAFC performance. Besides the fuel concentration, Jeong et al. reported that the thickness of the membrane also influences the crossover of formic acid, which affects the performance [11]. On the other hand, Kim et al. found that Nafion 117 was the best electrolyte membrane for $12 \mathrm{M}$ formic acid, with $84 \mathrm{~mW}$ $\mathrm{cm}^{-2}$ power density generated at $0.43 \mathrm{~V}[1]$.

In this study, the MEA is developed for the use of DFAFC. The effects of the backing layer, the loading of GDL, the carbon structures and the electrolyte membrane types, and fuel concentrations on the passive DFAFC's performance are investigated. The characterization of the electrode was analyzed, including the morphology structure, hydrophobicity level and electrical conductivity, and will be discussed on the basis of DFAFC performance.

\section{Fabrication of anode's diffusion layer and MEA}

\section{Materials and Methods}

Homogeneous carbon ink was prepared by ultrasonication of the carbon with $5 \%$ Nafion solution and isopropyl alcohol. The ink was coated on the backing layer to make the GDL and dried in an oven at $80^{\circ} \mathrm{C}$ for about an hour. At the anode side, two types of backing layer, i.e. carbon paper (CC) and carbon paper (CP), and three different carbon structures were used (shown in Table 1) and two GDL loadings were investigated at $1.0 \mathrm{mg} \mathrm{cm}^{-2}$ and 2.5 $\mathrm{mg} \mathrm{cm}$. For the cathode, CP with $2.5 \mathrm{mg} \mathrm{cm}^{-2} \mathrm{CB}$ loading was used throughout the study. Meanwhile, for the catalyst layer, $8 \mathrm{mg} \mathrm{cm}^{-2}$ catalyst loading of palladium (Pd) black (Alfa Aesar) was used as catalyst at the anode side, while platinum (Pt) black was used at the cathode side. For the electrolyte membrane, Nafion 117 (DuPont) and NRE 212 (DuPont) were used and the active area for the MEA was $4.84 \mathrm{~cm}^{2}$. For the MEA preparation, the 
anode and cathode were then assembled by the hot-pressed process with the electrolyte membrane at $135{ }^{\circ} \mathrm{C}$ and 50 $\mathrm{kg} \mathrm{cm}^{-2}$ for 3 minutes.

Table 1. Properties of carbon powder

\begin{tabular}{|c|c|c|}
\hline Carbon structure & Specification & Manufacturer \\
\hline Carbon black (CB) & $\begin{array}{l}\text { Purity }>99 \% \\
\text { Relative density } 1.7-1.9 \mathrm{~g} \mathrm{~cm}^{-3} \text { at } 20^{\circ} \mathrm{C}\end{array}$ & Cabot \\
\hline Carbon vaporised growth nanofiber (CNF) & $\begin{array}{l}\text { Outer diameter } 200-600 \mathrm{~nm} \\
\text { Length } 5-50 \mu \mathrm{m} \\
\text { Purity }>95.0 \%\end{array}$ & Cheaptubes \\
\hline Multiwall carbon nanotube (CNT) & $\begin{array}{l}\text { Outer diameter } 100-150 \mu \mathrm{m} \\
\text { Length } 20 \mu \mathrm{m} \\
\text { Purity } \geq 95\end{array}$ & Sigma- Aldrich \\
\hline
\end{tabular}

\section{Characterization of anode and single cell DFAFC operation}

The physicochemical properties and surface morphology of the GDL were observed with a contact angle measurement (KRÜSS Drop Shape Analysis by Fischer) and SEM (ZEISS), respectively. Contact angle measurements were done by using deionized water, methanol fuel $(0.5-2 \mathrm{M})$ and formic acid fuel $(0.5-6 \mathrm{M})$. SEM images were taken before the catalyst layers were coated onto the GDL. Meanwhile, the electrical conductivity test for the backing layer with different GDL was conducted by using the four point probes technique (Jandel Model RM3) to measure electrical resistivity towards the plane of the GDL. As a result, the through plane electrical conductivity of the GDL can be calculated by applying $5 \mathrm{~mA}$ current.

The electrochemical reaction for a half-cell as well as single cell DFAFC was measured and studied based on cyclic voltammetry (CV) and current-voltage (I-V) testing using WonATech potentiostat (WMPG1000). The CV test involved three electrodes, which are $\mathrm{Ag} / \mathrm{AgCl}$ as reference electrode, and platinum wire as counter electrode, while the working electrode used for the measurement was the anode prepared with different carbon structures with active area of $1 \mathrm{~cm}^{2}$. For the electrolyte of the half-cell reaction, $0.5 \mathrm{M} \mathrm{H}_{2} \mathrm{SO}_{4}$ was added to $0.5 \mathrm{M}$ formic acid to maintain a constant $\mathrm{pH}$ and stabilize the reference electrode potential. The scan rate for this electrochemical measurement was set at $50 \mathrm{mV} \mathrm{s}^{-1}$ in the range of 0.02 to $1.2 \mathrm{~V}$ and the electrochemical surface area (ECSA) was determined via $\mathrm{CV}$ analysis. For a single cell DFAFC, the cell was operated passively at $25^{\circ} \mathrm{C}$ with ambient pressure by injecting a formic acid solution at $5 \mathrm{ml}$ with a certain concentration from $4 \mathrm{M}$ to $16 \mathrm{M}$ into the reservoir under ambient conditions.

\section{Effect of backing layer and GDL loading}

\section{Results and Discussion}

The contact angle surfaces for the backing layer for a series of different concentrations of methanol and formic acid are shown in Figure 1. At this measurement, both commercial CC and CP were used without the GDL coated and had the same Teflon loading of $20 \mathrm{wt} . \%$. From the figure, it is clear that different levels of hydrophobicity were obtained at different liquid fuel concentrations. For instance, the contact angle is very similar, at $92^{\circ}$, using $2 \mathrm{M}$ methanol and $6 \mathrm{M}$ formic acid.

In the case of the hydrophobicity profile, the contact angle for carbon cloth and carbon paper with a solution of methanol decreased significantly with the decrease in the methanol concentration gradient from $0.5 \mathrm{M}$ to $2 \mathrm{M}$. However, for formic acid, the contact angle decreased with increasing formic acid concentration from $0.5 \mathrm{M}$ to $3 \mathrm{M}$ for both backing layers, while there was a significant decrease from $3 \mathrm{M}$ to $6 \mathrm{M}$ especially for carbon paper, as shown in Figure 1. The contact angle between the formic acid and carbon cloth is observed to be higher than with carbon paper. A similar tendency of the contact angle decreasing with the increasing concentration of formic acid was also obtained in previous studies by Uhm et al. [8]. 


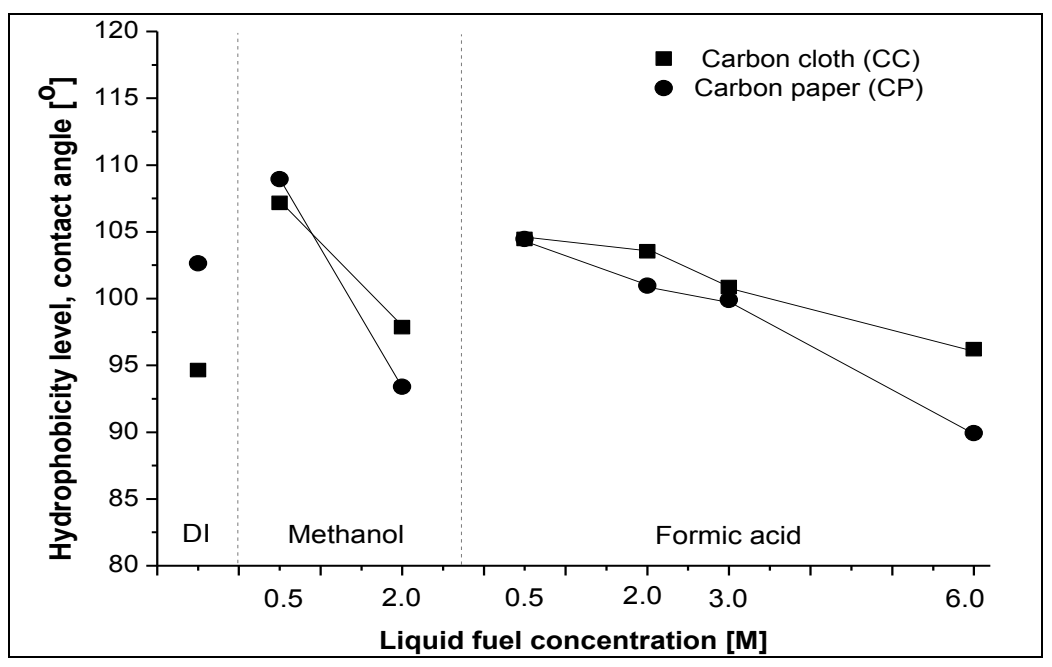

Figure 1. Hydrophobicity level for carbon support without GDL in different fuel concentrations

Nevertheless, the values of the contact angles for all backing layers with liquid fuel concentrations are greater than $90^{\circ}$, which indicates a hydrophobic surface layer of support. Chen et al. reported that a static contact angle between $0^{\circ}$ and $90^{\circ}$ was hydrophilic while a contact angle greater than $90^{\circ}$ was hydrophobic [12]. The wetting of porous solids also involves a contact angle phenomenon but it is complicated by the presence of a porous architecture that can be seen in the next section and shows the surface of the GDL. Konduru stated that a high reading of the contact angle and a rough surface on the carbon support and GDL restrict the accuracy of the contact angles [13]. In the case of formic acid fuel, Uhm et al. reported that the hydrophobicity level in the direct liquid fuel cell (DLFC) could control the liquid fuel transport to a certain extent for the reaction process and hence affected the performance of the cell [6]. Therefore, measuring the hydrophobicity level for different liquid fuel types and concentrations shows that the DMFC and DFAFC should have a different GDL or electrode structure to prevent the mass transport limitation of the fuel. Therefore, it is important to maintain the hydrophobicity level at the optimum condition in the GDL.

The GDL requires good electrical conductivity to support the catalyst and to ensure a good contact between the catalyst and ionomer material, which has an ionic contact with the electrolyte membrane [10]. Figure 2 shows the measurement data of electrical conductivity for different GDL structures, i.e., different backing layers and carbon structures, with $2.5 \mathrm{mg} \mathrm{cm}^{-2}$ carbon loading. From the figure, the backing layer without GDL provided a high conductivity. However, it has a drawback in terms of durability and this affects the water management in the electrode in order to prevent the flooding phenomenon. It was found that the GDL structure with CNT has the highest electrical conductivity compared with other microporous layers for both $\mathrm{CP}$ and $\mathrm{CC}$ at $1.25 \mathrm{~S} \mathrm{~cm}^{-1}$ and 1.46 $\mathrm{S} \mathrm{cm}^{-1}$, respectively. However, the electrical conductivity of the $\mathrm{CB}$ and $\mathrm{CNF}$ is still within the range of appropriate electrical conductivity of GDL, between $0.40 \mathrm{~S} \mathrm{~cm}^{-1}$ and $1.64 \mathrm{~S} \mathrm{~cm}^{-1}$ [14]. CNT has higher conductivity due to its unique structural, mechanical and electrical properties and also has a high aspect ratio to form a network of conductive tubes [15].

Moreover, it was observed that the electrical conductivity of the carbon cloth was higher than that of carbon paper. It was suggested that the carbon cloth with its highly porous structure provided a good support to build a uniform layer of GDL, and hence higher electrical conductivity was obtained. Figure 3 shows the performance of the DFAFC using different types of backing layer and GDL loading at the anode using $4 \mathrm{M}$ formic acid. In general, the power density for carbon cloth is lower than for carbon paper with the same structural carbon. This might be influenced by coarse structure in the carbon cloth's surface. The performance of each carbon support with different carbon structures with $2.5 \mathrm{mg} \mathrm{cm}^{-2}$ loading is low. 


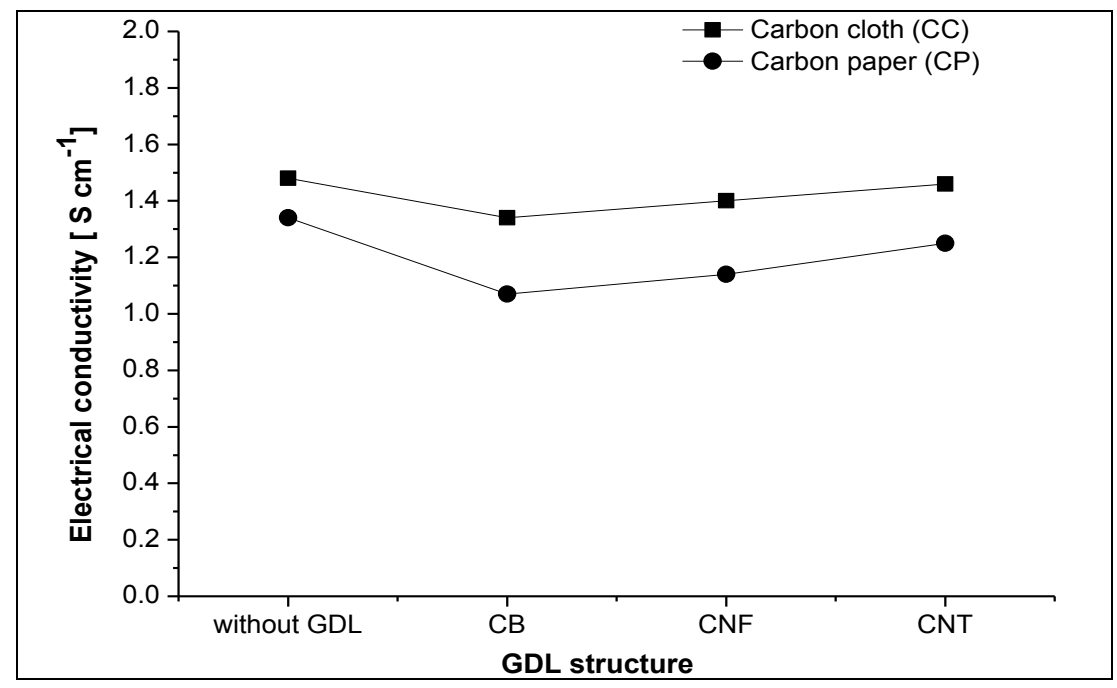

Figure 2. Electrical conductivity for different structures of GDL

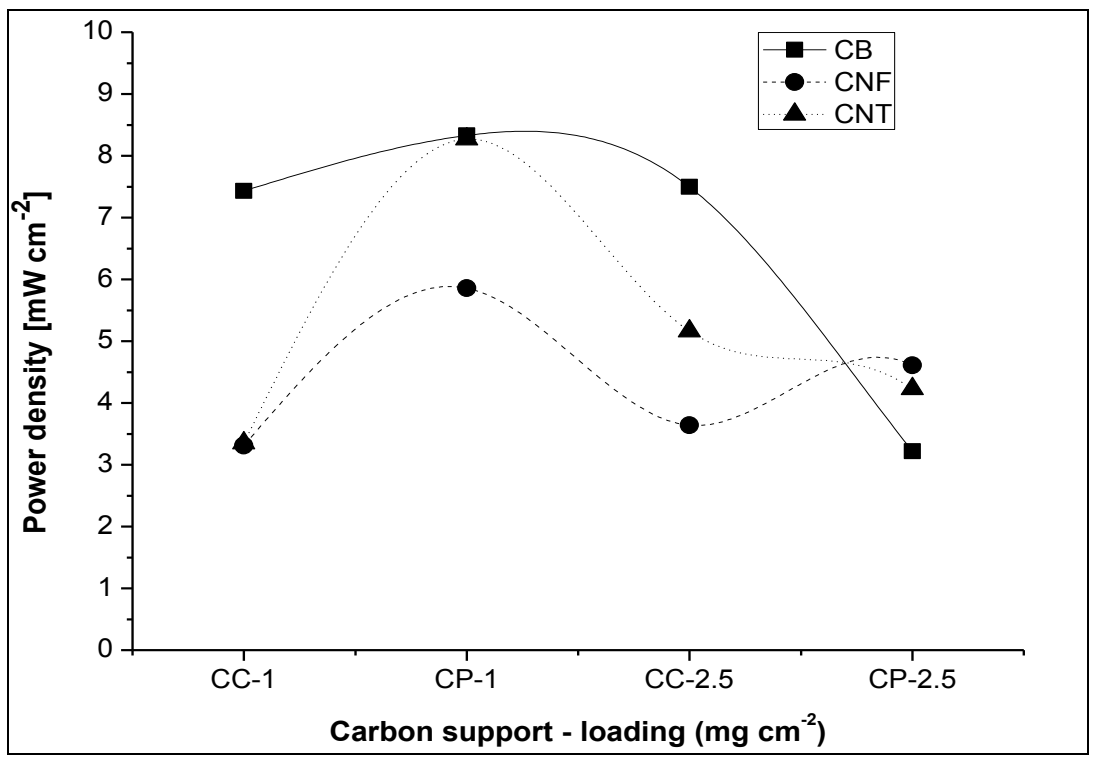

Figure 3. DFAFC performances for different types of carbon and loading at $4 \mathrm{M}$ formic acid

From the observation, the microstructure layer with $\mathrm{CP}$ as support with a loading of $1.0 \mathrm{mg} \mathrm{cm}^{-2}$ (CP-1) recorded the highest power density. The porous structure of carbon cloth causes all the ink of the carbon to diffuse to the carbon support. This phenomenon prevents the GDL surface giving good support as a catalyst layer. This explains the maximum power density obtained by the carbon loading of $2.5 \mathrm{mg} \mathrm{cm}^{-2}$ of carbon black compared to other microstructures (CNF and CNT) with carbon cloth. As the size of the nanostructure particles decreases, they tend to agglomerate during the ultrasonication process, which hinders the absorption of fuel to react with the catalyst. Therefore, it is easier for the CB to achieve the homogeneous level compared to the other carbon powder. Hence, the high loading $\left(2.5 \% \mathrm{mg} \mathrm{cm}^{-2}\right)$ of CNF and CNT is not preferable for this application. 
However, CNF and CNT with $1.0 \mathrm{mg} \mathrm{cm}^{-2}$ loading at the $\mathrm{CC}$ diffuse more easily due to the pore size. Hence, using $\mathrm{CP}$ that requires a loading of $1.0 \mathrm{mg} \mathrm{cm}^{-2}$ is preferable because it offers good diffusion for the catalyst to react with the formic acid as fuel. From the results, carbon powders achieve higher performance for all layers of the microstructure. $\mathrm{CP}$ with a loading of $1.0 \mathrm{mg} \mathrm{cm}^{-2}$ microstructure for both $\mathrm{CB}$ and CNT recorded high performances, at $8.15 \mathrm{~mW} \mathrm{~cm}^{-2}$ and $8.27 \mathrm{~mW} \mathrm{~cm}^{-2}$, respectively. From the results acquired, carbon paper as the support layer will provide a better performance with a loading of $1.0 \mathrm{mg} \mathrm{cm}^{-2}$ than with $2.5 \mathrm{mg} \mathrm{cm}^{-2}$. Therefore, $\mathrm{CP}$ with a loading of $1 \mathrm{mg} \mathrm{cm}^{-2}$ was used as the backing layer for the following study to fabricate the anode.

\section{Effect of carbon structure, electrolyte membrane and fuel concentrations}

Figure 4 shows the image of the anode's GDL morphology structure through SEM using different carbon structures at the carbon paper: a) without GDL; b) CB; c) CNF), and d) CNT. As seen in Fig. 4, different structures can be observed with different carbon structures or without the GDL. By comparing the morphology, it is clear that the CP without a microporous layer of GDL has a surface layer of coarse fibers compared with a GDL.
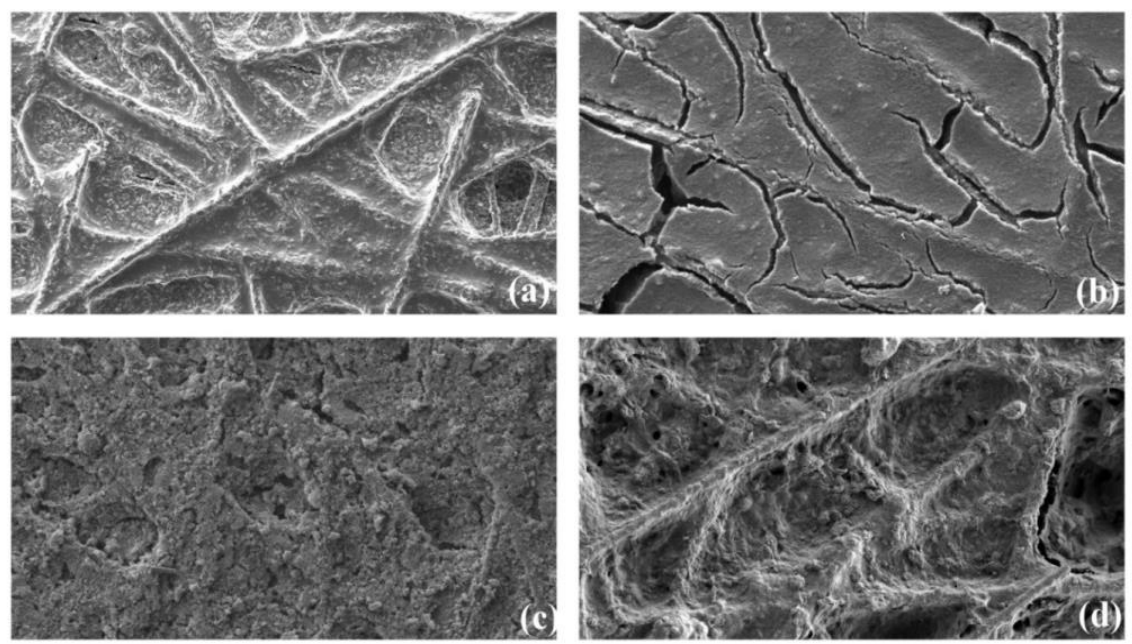

Figure 4. SEM images of CP support with GDL loading $1.0 \mathrm{mg} \mathrm{cm}^{-2}$ for (a) without GDL, (b) CB, (c) CNF and (d) CNT at $200 \mathrm{X}$ magnification and a scale of $100 \mu \mathrm{m}$

The structure of the GDL with CB gives a smoother surface than without a microporous layer support. However, the GDL with CB (Figure 4 (b)) results in a cracking layer which increases the loss of the catalyst because it may be adsorbed on the cracked microporous layer. Figure 4 (c) and (d) shows that the dispersion of carbon ink CNF and CNT is more even. The CNT structure in Figure 4 (d) presents some of the carbon fiber from the carbon paper due to the smaller size of CNT compared to CNF, as previously mentioned in Table 1. The smooth surface ensures good GDL contact with the catalyst layer, but also nanostructured carbon can be used to improve the electrical properties and structure of the GDL [16] for the DFAFC.

Figure 5 shows the CV test on the anode with different GDL-Pd coatings for carbon paper as a backing layer with $1.0 \mathrm{mg} \mathrm{cm}^{-2} \mathrm{GDL}$ loading. From Figure 5, the peak of the reaction, recorded at $0.6-0.75 \mathrm{~V}$, may be associated with the rate of reaction on the Pd catalyst layers with different adsorption. The electrochemical surface area (ECSA) values for CB-Pd, CNF-Pd and CNT-Pd are $12.81 \mathrm{~cm}^{2} \mathrm{mg}^{-1}, 21 \mathrm{~cm}^{2} \mathrm{mg}^{-1}$ and $23.58 \mathrm{~cm}^{2} \mathrm{mg}^{-1}$ respectively. It can be seen that the rate of reaction with a CNT anode as the absorption layer is higher than with the CB and CNF, achieving a current density of $22.3 \mathrm{~mA} \mathrm{~cm}^{-2}$ with the same pattern of curves. Smaller ECSA value for CB indicating lower electrocatalytic activity towards formic acid reaction compared to CNT as catalyst support. 


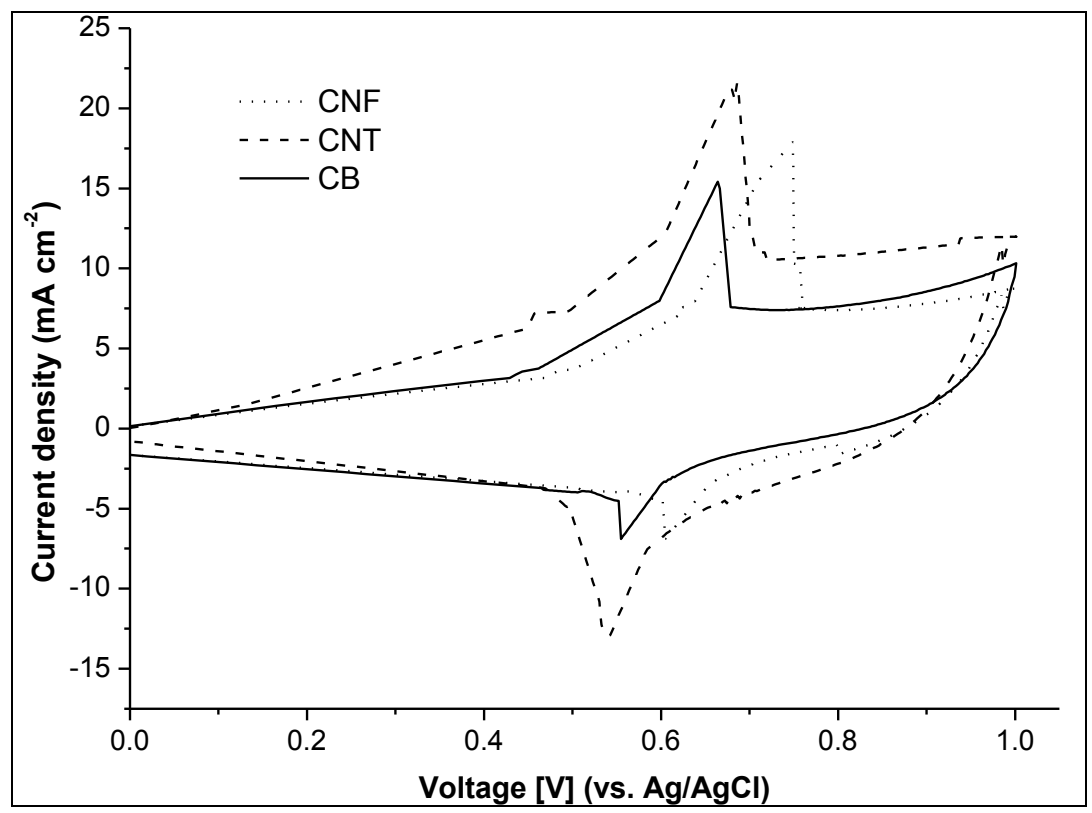

Figure 5. Cyclic voltammetry for anode with different structures of GDL

The CB carbon structure that is commonly used has the problem of elemental sulfur impurities and pores that trap microporous nanoparticles and degrade the catalyst activity. In addition, it is also thermochemically unstable, which inhibits the DFAFC's ability to curb erosion events on the carbon support, which deteriorates when in contact with the catalyst support [9].

Figure 6 shows the maximum power density obtained for different types of membrane and carbon structure. The different in electrode structures (by using different carbon material) would affect the MEA, and hence affect the cell performance. These indicate the different between current and power densities (shown in the Fig. 5 and Fig. 6, respectively) for different carbons used are due to the different in their carbon properties. The CNT showed a highest performance of current and power density compared to that CB and CNF. In general, the polarization curve profile for DFAFCs is similar, where the samples obtained show lower performance, i.e., maximum power density, at low fuel concentrations, and increase with concentration until the optimum concentration. From Fig. 6 it can be seen that the optimum concentration for the DFAFC for every sample is $10 \mathrm{M}$, whereas only one sample, N117-CP$\mathrm{CNF}$, achieved the maximum power density on a formic acid concentration of $13 \mathrm{M}$. The performance drops after the optimum concentration is achieved.

At low concentrations, formic acid cannot accommodate fuel operation at a high current density due to the presence of the mass transport limit [17]. The formic acid concentration of $10 \mathrm{M}$ is the optimum concentration acquired, which matches the results of studies by past researchers $[1,17,18]$. However, when the concentration increases from the optimum concentration and above until $16 \mathrm{M}$, the DFAFC performance will decrease due to low catalyst activity and the occurrence of fuel flux crossing [1, 18]. The decline in performance at high formic acid concentrations may also be caused by the very nature of formic acid, which is hydrophilic and thus dries the layer near the membrane, which can inhibit proton transfer [19]. Meanwhile, Nafion 117 membrane gives a much higher performance overall, with a range of $10.43 \mathrm{~mW} \mathrm{~cm}^{-2}$ to $18.36 \mathrm{~mW} \mathrm{~cm}^{-2}$ compared to NRE 212 membrane with a range of $6.77 \mathrm{~mW} \mathrm{~cm}^{-2}$ to $8.91 \mathrm{~mW} \mathrm{~cm}^{-2}$. As the NRE 212 membrane thickness is very similar to Nafion 112 membrane, the finding by Rhee et al. that the rate of crossing for Nafion 112 is higher compared to Nafion 117 indicates the same cause of the decline of performance in this study [19]. For a cell that uses CNF carbon structure as the GDL with NRE 212 membrane, the optimum concentration that is acquired by this cell is different from the use of N117, which is $10 \mathrm{M}$, like the optimum concentration achieved by other MEAs. The highest maximum power 
density that is achieved for MEAs is $7.67 \mathrm{~mW} \mathrm{~cm}^{-2}$ for the $10 \mathrm{M}$ and the lowest is $4.10 \mathrm{~mW} \mathrm{~cm}{ }^{-2}$ for the $4 \mathrm{M}$ of formic acid fuel.

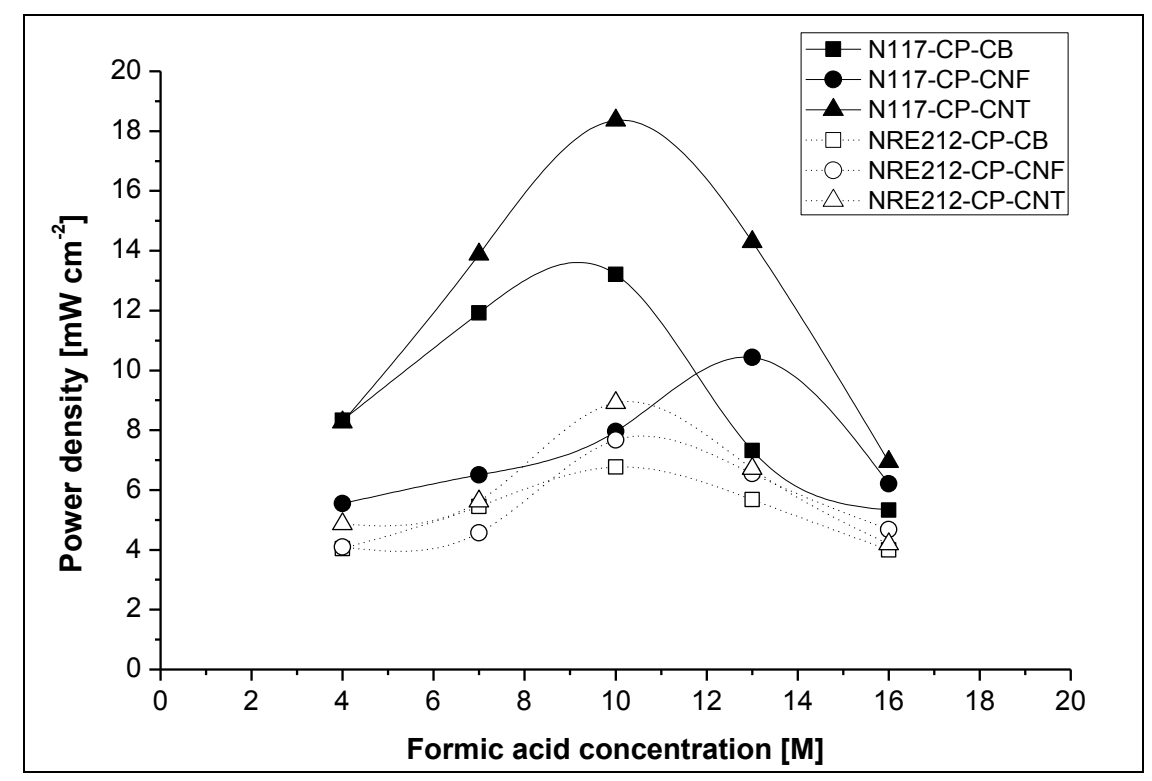

Figure 6. Single cell performance with different MEA combinations for 4-16 M formic acid

Overall, single cell performance using N117 electrolyte membrane gives a higher performance compared to the use of NRE 212 membrane. The decline in performance with the use of NRE 212 membrane is the same as found in research by Tsujiguchi et al., who state that formic acid flux is the highest compared to N115 and N117 membrane [20]. This further reinforces the main reason for the decline in performance that occurs when using NRE 212 membrane. According to Park et al., the diffusion layer can increase the overall performance of the catalyst and fuel cell depending on its structure [21].

\section{Conclusion}

The effects of the backing layer, carbon structures, carbon loading and membrane thickness on DFAFC performance were investigated in order to fabricate high performance of MEA. The maximum power density of $18.36 \mathrm{~mW} \mathrm{~cm}^{-2}$ was obtained by using the combination of $\mathrm{CP}$ as carbon support with a $1.0 \mathrm{mg} \mathrm{cm}^{-2} \mathrm{CNT}$ layer and $\mathrm{N} 117$ as the electrolyte membrane at $10 \mathrm{M}$ formic acid. High ECSA values for CNT as catalyst support for Pd in $\mathrm{CV}$ testing indicate that CNT have high potential to reduce the loading of catalyst usage due to the improve catalyst utilization. Hence, it can give a good support for efficient catalyst utilization as well as reduce the cost. Therefore, a good and thorough understanding of electrode structure and electrochemical properties is needed in order to increase the performance and durability of passive DFAFCs for mobile power sources.

\section{Acknowledgement}

This study was supported partially by ERGS/1/2011/TK/UKM/03/17 and FRGS/1/2013/TK07/UKM/02/1 from the Ministry of Higher Education, Malaysia and GUP-2014-069, DLP-2013-026 from Universiti Kebangsaan Malaysia.

\section{References}

1. Kim, H. S., Morgan, R. D., Gurau, B. and Masel, R. I. (2009). A miniature direct formic acid fuel cell battery. Journal of Power Sources, 188(1): 118 - 121. 
2. Miesse, C. M., Jung, W. S., Jeong, K.-J., Lee, J. K., Lee, J., Han, J., Yoon, S. P., Nam, S. W., Lim, T.-H. and Hong, S.-A. (2006). Direct formic acid fuel cell portable power system for the operation of a laptop computer. Journal of Power Sources, 162(1): $532-540$.

3. Ahmad, M. M., Kamarudin, S. K. and Daud, W. R. W. (2010). Design of and optimal micro direct methanol fuel cell for portable applications. Sains Malaysiana 39(3):467 - 472.

4. Hashim, N., Kamarudin, S.K. and Daud, W. R. W. (2010). Design and development of micro direct methanol fuel cell. Sains Malaysiana, 39(6): 1015 - 1023

5. Jaafar, J, Ismail, A. F., Matsuura, T. and Mohd Nordin, M. N. A. (2013). Stability of SPEEK-triaminopyrimide polymer electrolyte membrane for direct methanol fuel cell application. Sains Malaysiana, 42(11):1671 - 1677.

6. Uhm, S., Chung, S. T. and Lee, J. (2008). Characterization of direct formic acid fuel cells by impedance studies: in comparison of direct methanol fuel cells. Journal of Power Sources, 178(1): $34-43$.

7. Kim, S., Han, J., Kwon, Y., Lee, K.-S., Lim, T.-H., Nam, S. W. and Jang, J. H. (2011). Effect of nafion ionomer and catalyst in cathode layers for the direct formic acid fuel cell with complex capacitance analysis on the ionic resistance. Electrochimica Acta, 56(23): 7984 - 7990.

8. Uhm, S., Lee, J. K., Chung, S. T. and Lee, J. (2008). Effect of anode diffusion media on direct formic acid fuel cells. Journal of Industrial and Engineering Chemistry, 14(4): 493 - 498.

9. Sharma, S. and Pollet, B. G. (2012). Support materials for PEMFC and DMFC electrocatalysts - A review. Journal of Power Sources, 208(0): 96 - 119.

10. Zainoodin, A. M., Kamarudin, S. K. and Daud, W. R. W. (2010). Electrode in direct methanol fuel cells. International Journal of Hydrogen Energy, 35(10): 4606 - 4621.

11. Jeong, K-J, Miesse, C. M., Cho,i J-H., Lee, J., Han, J. and Yoon, S. P. (2007). Fuel crossover in direct formic acid fuel cells. Journal of Power Sources, 168: $119-125$.

12. Chen, W.-H., Ko, T.-H., Lin, J.-H., Liu, C.-H., Shen, C.-W. and Wang, C.-H. (2011). Influences of gas diffusion layers with pitch-based carbon coated in polymer electrolyte membrane fuel cell. International Journal of Electrochemical Science, 6: 2192 - 2200.

13. Konduru, V. (2010). Static and dynamic contact angle measurement on rough surfaces using sessile drop profile analysis with application to water management in low temperature fuel cells. Michigan Technological University.

14. Litster, S. and Mclean, G. (2004). PEM fuel cell electrodes. Journal of Power Sources, 130(1): 61 - 76.

15. Choi, J. and Zhang, Y. (2015). Properties and applications of single-, double- and multi-walled carbon nanotubes. Sigma Aldrich. Access online [26 May 2015].

16. Sundarrajan, S., Allakhverdiev, S. I. and Ramakrishna, S. (2012). Progress and perspectives in micro direct methanol fuel cell. International Journal of Hydrogen Energy, 37(10): 8765 - 8786.

17. Zhu, Y., Ha, S. Y. and Masel, R. I. (2004). High power density direct formic acid fuel cells. Journal of Power Sources, 130(1-2): 8 - 14 .

18. Ha, S., Dunbar, Z. and Masel, R. I. (2006). Characterization of a high performing passive direct formic acid fuel cell. Journal of Power Sources, 158(1): $129-136$.

19. Rhee, Y.-W., Ha, S. Y. and Masel, R. I. (2003). Crossover of formic acid through Nafion ${ }^{\circledR}$ membranes. Journal of Power Sources, 117(2): 35 - 38.

20. Tsujiguchi, T., Iwakami, T., Hirano, S. and Nakagawa, N. (2014). Water transport characteristics of the passive direct formic acid fuel cell. Journal of Power Sources, 250: 266 - 273

21. Park, S., Lee, J-W. and Popov, B. N. (2006). Effect of carbon loading in microporous layer on PEM fuel cell performance. Journal of Power Sources, 163:357 - 363. 